\title{
Legumes in Chinese Natural Grasslands: Species, Biomass, and Distribution
}

\author{
Dongmei Jin, ${ }^{1}$ Jianjing $\mathrm{Ma},{ }^{2}$ Wenhong $\mathrm{Ma},{ }^{3}$ Cunzhu Liang, ${ }^{4}$ Yue Shi, ${ }^{2}$ and Jin-Sheng $\mathrm{He}^{5,6}$
}

Authors are ${ }^{1}$ Postdoctoral Fellow, ${ }^{2}$ Master Student, and ${ }^{5}$ Professor, Dept of Ecology, and Key Laboratory for Earth Surface Processes of the Ministry of Education, Peking University, Beijing 100871, China; ${ }^{3}$ Associate Professor and ${ }^{4}$ Professor, Dept of Ecology, Inner Mongolia University, Hohbot 010021, China; and ${ }^{6}$ Professor, Key Laboratory of Adaptation and Evolution of Plateau Biota, Northwest Institute of Plateau Biology, Chinese Academy of Sciences, Xining 810008, China.

\begin{abstract}
The composition and abundance of legumes affect the economic value and ecological sustainability of natural grasslands. We collected data on species richness and aboveground biomass of legumes and their percentages of the total community at 78 field sites in Chinese natural grasslands on the Tibetan Plateau (alpine steppe and alpine meadow) and in Inner Mongolia (meadow steppe, typical steppe, and desert steppe), and analyzed the association between these attributes with community, climate, and soil factors. At least one legume species occurred in $89.7 \%$ of the sites studied; the genera Astragalus, Oxytropis, and Medicago were dominant among the 12 legume genera recorded. Generally, within $1 \mathrm{~m}^{2}$ of grassland, only one legume species was present with an aboveground biomass of $1.1 \mathrm{~g}$; this accounted for $9.1 \%$ of community species richness and $1.7 \%$ of total aboveground biomass. In comparison with many other types of grassland around the world, both the legume aboveground biomass and its percentage of the total were low in Chinese grasslands, especially in Inner Mongolia. The low biomass of legumes in grassland might be attributable to the low growing-season temperature on the Tibetan Plateau, while in Inner Mongolia, low precipitation combined with high temperatures during the growing season may be the main reason. Although legumes in Chinese grasslands have substantial potential for nitrogen fixation and contain a variety of forage species, their ecological and economic value has been limited by their low biomass. Suggestions to enhance legume biomass in Chinese grasslands are provided.
\end{abstract}

Key Words: aboveground biomass, Inner Mongolia, nitrogen fixation, species richness, steppe, Tibetan Plateau

\section{INTRODUCTION}

Legumes, species that belong to the Fabaceae family, are significant components of nearly all terrestrial biomes (Schrire et al. 2005). In grassland areas, which cover $26 \%$ of the terrestrial area on the earth (Food and Agriculture Organization of the United Nations 2013), legumes are important for both economic prosperity and ecosystem sustainability. Legumes such as alfalfa (Medicago sativa) and clover (Trifolium spp.) are the foundation of milk and animal production for many countries (Rochon et al. 2004; Dewhurst et al. 2009). That is because they are often rich in protein and have a desirable amino acid composition (Dewhurst et al. 2009), which may benefit from their ability to form root nodules with rhizobia and fix atmospheric nitrogen (N). From an ecological aspect, pasture and fodder legumes are a major source of $\mathrm{N}$ in grassland ecosystems, fixing $110-227 \mathrm{~kg} \cdot \mathrm{ha}^{-1}$ of $\mathrm{N}$ or about 12-25 Tg globally each year (Smil 1999; Herridge et al. 2008). At the community level, N-fixing legumes are shown to increase community primary production (Marquard et al. 2009; Schmidtke et al. 2010) by improving soil N availability for associated nonfixers (Spehn et al. 2002; Roscher et al. 2011). Despite the above benefits, previous studies on legumes have focused mainly on a few cultivated species in managed

\footnotetext{
Research was funded in part by the National Natural Science Foundation of China (Grants 31025005 and 31270481), and the Strategic Priority Research Program of the Chinese Academy of Sciences (Grant XDA05050304).

Correspondence: Jin-Sheng He, Dept of Ecology, College of Urban and Environmental Sciences, Peking University, 5 Yiheyuan Rd, Beijing 100871, China. E-mail: jshe@ pku.edu.cn
}

(c) 2013 The Society for Range Management grasslands; in comparison, research on legume diversity and abundance in natural grassland is scarce. More research is needed to assess the actual importance of legumes in natural grasslands (Sprent and Gehlot 2010).

Across China, there are about 1670 legume species from 180 genera (Zhu et al. 2007), the majority of which can be found in grassland areas and have the potential to be used as livestock forage (Xu 2004). Moreover, about 500 legume species from 118 genera have been found to nodulate (Chen and Wang 2011). Nevertheless, few studies have investigated legume species composition, richness, or abundance in natural grasslands. As a result, the economic and ecological importance of legumes in Chinese grasslands are still unexplored.

In China, diverse types of natural grassland cover an area of 400 million ha, comprising $41.7 \%$ of the total land area; and range mainly from northeastern Inner Mongolia in the temperate zone to the Tibetan Plateau (Kang et al. 2007). On the Tibetan Plateau, which has an average altitude over 4000 $\mathrm{m}$, alpine meadows are dominated by perennial hygrophilous grasses like Kobresia pygmaea and K. humilis, and alpine steppe areas are dominated by perennial tussock grasses like Stipa purpurea and S. breviflora. In Inner Mongolia, where the average altitude is about $1000 \mathrm{~m}$, the grassland type changes from meadow steppe (dominated by S. baicalensis or Leymus chinensis) to typical steppe (dominated by $S$. grandis or $S$. sareptana var. krylovii) to desert steppe (dominated by $S$. gobica or S. tianschanica var. klemenzii) as mean annual precipitation decreases, but temperature increases, from northeast to southwest. All the mentioned grasslands are characterized by a continental climate, with about $85 \%$ of the annual precipitation falling during the growing season 


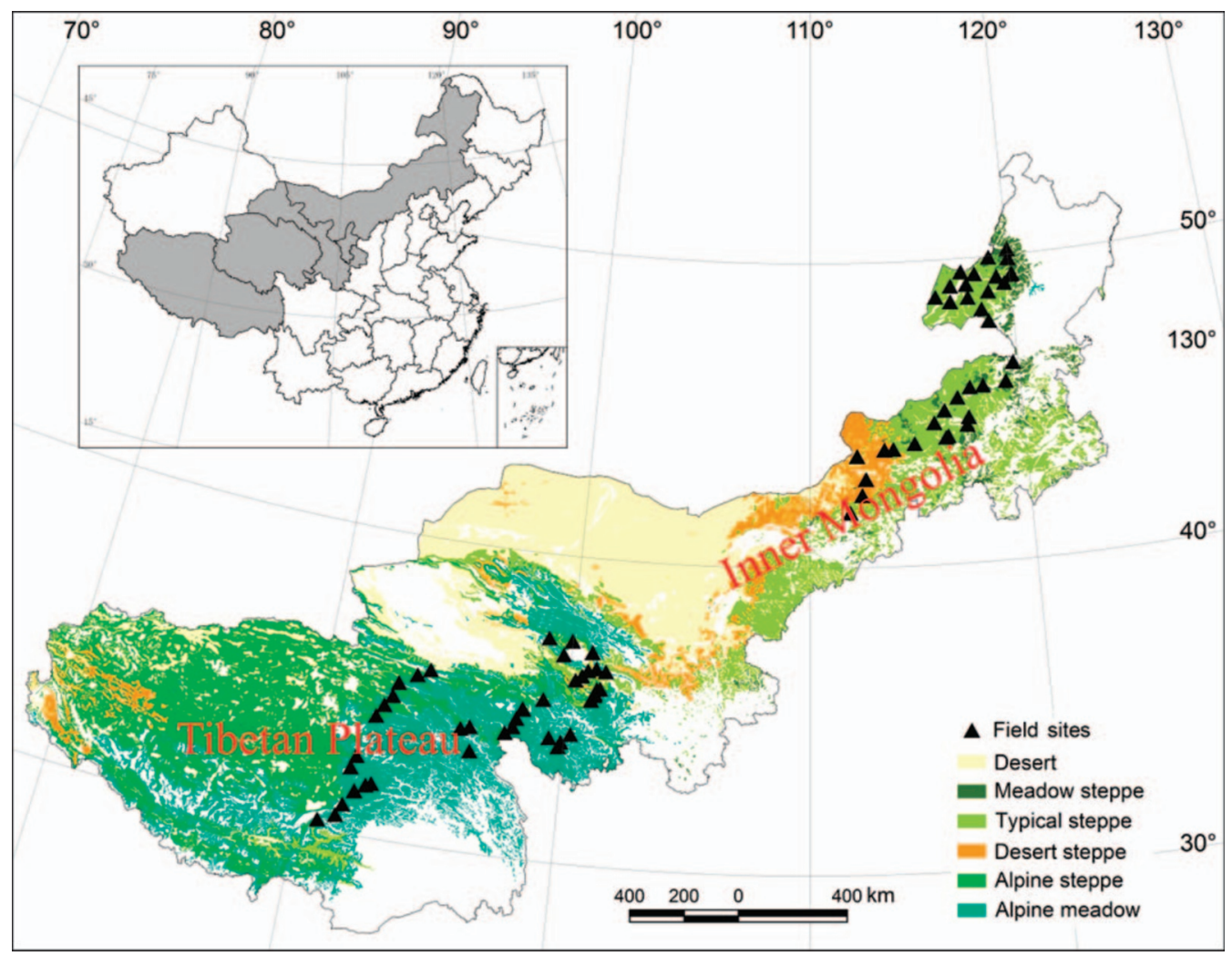

Figure 1. Location of sampling sites with a background of grassland distributions adapted from the Vegetation Atlas of China (Chinese Academy of Sciences, Editorial Committee of Vegetation Map of China, 2007; reproduced with permission).

(May to September). Open livestock grazing with neither fertilization nor irrigation is the major utilization of natural grasslands in China. In recent decades, overgrazing has become the main cause of large-scale grassland degradation (Jiang et al. 2006 ), and about $23 \%$ of the grassland area on the Tibetan Plateau and 60\% in Inner Mongolia are degraded (Li 1997).

Through a large-scale inventory of legumes in Chinese grasslands, we aimed (1) to document the composition of legumes in different regions and grassland types; (2) to quantify the species richness, aboveground biomass, and percentages of legumes in these communities; and (3) to detect the environmental factors (biotic, climatic, or edaphic) that are likely to regulate the diversity and biomass of legumes.

\section{METHODS}

\section{Site Description}

During the summers of 2006 and 2007, we sampled 78 sites spanning five dominant types of natural grassland in China; 43 sites were on the Tibetan Plateau and 35 sites were in Inner Mongolia (Fig. 1). The study area covered a wide variety of geographic features, climatic attributes, and edaphic characteristics (Table 1).

\section{Data Collection}

At each site, one $10 \times 10 \mathrm{~m}$ quadrat was randomly located, within which three $1 \times 1 \mathrm{~m}$ plots along a diagonal line were surveyed. In each plot, plant species were recorded, and aboveground biomass was harvested at ground level and separated into two categories: legumes and nonlegumes. Plant samples were oven-dried at $65{ }^{\circ} \mathrm{C}$ for $72 \mathrm{hr}$ to a constant weight, and weighed to the nearest milligram. For each plot, we listed legume species richness and aboveground biomass, as well as community species richness and total aboveground biomass. The percentages of legume species richness and aboveground biomass relative to the totals were also calculated. Data for each site were averaged across the three plots. In addition to the collection of plant samples, three soil samples were collected from $0-10 \mathrm{~cm}$ depth for each site, one from each plot. After all living materials were removed, soil samples were air-dried and ground using a ball mill (NM200, Retsch, Germany). Total soil $\mathrm{N}$ concentration was measured using an elemental analyzer (2400 Series II CHNS/O Elemental Analyzer, PerkinElmer, USA). Soil organic carbon content was calculated as the difference between soil total carbon content, which was measured by dry combustion using an elemental analyzer (VARIO EL III, Elementar, Germany), and soil inorganic carbon content, which was measured using an inorganic carbon analyzer (08.53 Calcimeter, Eijkelkamp, The Netherlands). Soil available phosphorus concentration was measured by extraction with sodium bicarbonate (Olsen et al. 1954). Climate data for each site, including growing-season temperature and precipitation, were compiled from a global climate database (Hijmans et al. 2005) with a resolution of $1 \times$ $1 \mathrm{~km}$. 
Table 1. Description of five grassland types from two regions in China. The mean value and standard error of the parameters are shown, and the ranges are given in parentheses.

\begin{tabular}{|c|c|c|c|c|c|c|c|}
\hline & $\begin{array}{l}\text { No. } \\
\text { of sites }\end{array}$ & $\begin{array}{l}\text { Altitude } \\
(\mathrm{m})\end{array}$ & $\begin{array}{l}\mathrm{GST}^{1} \\
\left({ }^{\circ} \mathrm{C}\right)\end{array}$ & $\begin{array}{c}\text { GSP } \\
\left(\mathrm{mm} \cdot \mathrm{yr}^{-1}\right)\end{array}$ & $\begin{array}{l}\text { STN } \\
(\%)\end{array}$ & $\begin{array}{c}\text { SAP } \\
\left(\mu \mathrm{g} \cdot \mathrm{g}^{-1}\right)\end{array}$ & $\begin{array}{l}\text { SOC } \\
(\%)\end{array}$ \\
\hline & 78 & $\begin{array}{r}2647 \pm 193 \\
\quad(553-5105)\end{array}$ & $\begin{array}{c}10.7 \pm 0.5 \\
(3.1-18.4)\end{array}$ & $\begin{array}{l}297 \pm 8 \\
(126-463)\end{array}$ & $\begin{array}{l}0.38 \pm 0.04 \\
(0.04-1.64)\end{array}$ & $\begin{array}{l}7.2 \pm 0.7 \\
(1.2-26.7)\end{array}$ & $\begin{array}{l}3.36 \pm 0.38 \\
(0.34-19.30)\end{array}$ \\
\hline \multicolumn{8}{|l|}{ Region } \\
\hline Tibetan Plateau & 43 & $\begin{array}{l}4112 \pm 93 \\
(2925-5105)\end{array}$ & $\begin{array}{l}6.7 \pm 0.3 \\
(3.1-11.9)\end{array}$ & $\begin{array}{l}329 \pm 10.5 \\
(151-463)\end{array}$ & $\begin{array}{l}0.52 \pm 0.05 \\
(0.10-1.64)\end{array}$ & $\begin{array}{l}9.9 \pm 0.99 \\
(1.2-26.7)\end{array}$ & $\begin{array}{l}4.43 \pm 0.57 \\
(0.34-19.30)\end{array}$ \\
\hline Inner Mongolia & 35 & $\begin{array}{l}848 \pm 39 \\
(553-1422)\end{array}$ & $\begin{array}{l}15.6 \pm 0.2 \\
(12.8-18.4)\end{array}$ & $\begin{array}{l}259 \pm 10 \\
(126-370)\end{array}$ & $\begin{array}{l}0.18 \pm 0.02 \\
(0.04-0.39)\end{array}$ & $\begin{array}{l}3.3 \pm 0.2 \\
(1.6-6.7)\end{array}$ & $\begin{array}{l}1.76 \pm 0.2 \\
(0.35-4.87)\end{array}$ \\
\hline \multicolumn{8}{|l|}{ Grassland type } \\
\hline Alpine meadow & 25 & $\begin{array}{l}4264 \pm 105 \\
(3302-5105)\end{array}$ & $\begin{array}{l}6.2 \pm 0.4 \\
(3.1-9.4)\end{array}$ & $\begin{array}{l}360 \pm 11 \\
(255-463)\end{array}$ & $\begin{array}{l}0.71 \pm 0.07 \\
(0.19-1.64)\end{array}$ & $\begin{array}{c}13.7 \pm 1.1 \\
(4.8-26.7)\end{array}$ & $\begin{array}{l}6.51 \pm 0.73 \\
(1.46-19.30)\end{array}$ \\
\hline Alpine steppe & 18 & $\begin{array}{c}3902 \pm 156 \\
(2925-4756)\end{array}$ & $\begin{array}{l}7.5 \pm 0.6 \\
(3.2-11.9)\end{array}$ & $\begin{array}{l}284 \pm 14 \\
(151-376)\end{array}$ & $\begin{array}{l}0.24 \pm 0.03 \\
(0.10-0.52)\end{array}$ & $\begin{array}{l}4.5 \pm 0.5 \\
(1.2-10.4)\end{array}$ & $\begin{array}{l}1.54 \pm 0.22 \\
(0.34-3.54)\end{array}$ \\
\hline Meadow steppe & 7 & $\begin{array}{l}804 \pm 79 \\
(571-1080)\end{array}$ & $\begin{array}{l}14.3 \pm 0.3 \\
(12.8-15.0)\end{array}$ & $\begin{array}{l}330 \pm 9.8 \\
(289-370)\end{array}$ & $\begin{array}{l}0.27 \pm 0.05 \\
(0.10-0.39)\end{array}$ & $\begin{array}{l}4.2 \pm 0.7 \\
(2.4-6.7)\end{array}$ & $\begin{array}{l}2.92 \pm 0.60 \\
(1.02-4.87)\end{array}$ \\
\hline Typical steppe & 22 & $\begin{array}{l}781 \pm 41 \\
(553-1152)\end{array}$ & $\begin{array}{l}15.5 \pm 0.11 \\
(14.2-16.4)\end{array}$ & $\begin{array}{l}261 \pm 7.2 \\
(203-341)\end{array}$ & $\begin{array}{l}0.16 \pm 0.02 \\
(0.04-0.35)\end{array}$ & $\begin{array}{l}3.3 \pm 0.2 \\
(1.8-5.5)\end{array}$ & $\begin{array}{l}1.58 \pm 0.18 \\
(0.35-3.82)\end{array}$ \\
\hline Desert steppe & 6 & $\begin{array}{l}1144 \pm 68 \\
(955-1422)\end{array}$ & $\begin{array}{l}17.5 \pm 0.3 \\
(16.3-18.4)\end{array}$ & $\begin{array}{l}168 \pm 9.6 \\
(126-192)\end{array}$ & $\begin{array}{l}0.10 \pm 0.02 \\
(0.06-0.12)\end{array}$ & $\begin{array}{l}1.8 \pm 0.2 \\
(1.6-2.1)\end{array}$ & $\begin{array}{l}0.66 \pm 0.20 \\
(0.36-1.05)\end{array}$ \\
\hline
\end{tabular}

GST indicates growing-season temperature (May to September); GSP, growing-season precipitation; STN, total soil nitrogen concentration; SAP, soil available phosphorus concentration; and SOC, soil organic carbon concentration.

\section{Data Analysis}

First, the dominant legume genera in Chinese grasslands were determined by their frequency of occurrence across all sites, as well as for each region and grassland type. To distinguish forage from nonforage species, each legume species recorded was checked against the China Forage Catalog (Grassland Research Institute of Chinese Academy of Agricultural Sciences 2009). Legumes known to contain a variety of alkaloids toxic to livestock were also identified (Xi and Ma 2003; Wang et al. 2007). Second, we applied Standardized Major Axes regression (Warton and Ormerod 2007) to analyze the relationships

Table 2. Frequency of legume genera in 78 sites on Chinese grasslands. The numbers represent the percentage (\%) of sites where a genus was found in a given category.

\begin{tabular}{|c|c|c|c|c|c|c|c|c|}
\hline \multirow[b]{2}{*}{ Genus } & \multirow[b]{2}{*}{ All } & \multicolumn{2}{|c|}{ Region } & \multicolumn{5}{|c|}{ Grassland type } \\
\hline & & $\begin{array}{l}\text { Tibetan } \\
\text { Plateau }\end{array}$ & $\begin{array}{c}\text { Inner } \\
\text { Mongolia }\end{array}$ & $\begin{array}{c}\text { Alpine } \\
\text { meadow }\end{array}$ & $\begin{array}{l}\text { Alpine } \\
\text { steppe }\end{array}$ & $\begin{array}{c}\text { Meadow } \\
\text { steppe }\end{array}$ & $\begin{array}{l}\text { Typical } \\
\text { steppe }\end{array}$ & $\begin{array}{l}\text { Desert } \\
\text { steppe }\end{array}$ \\
\hline Astragalus & 67.9 & 60.5 & 77.1 & 48.0 & 77.8 & 57.1 & 86.4 & 66.7 \\
\hline Oxytropis & 34.6 & 53.5 & 11.4 & 72.0 & 27.8 & 42.9 & 4.5 & \\
\hline Medicago & 21.8 & 14.0 & 31.4 & 20.0 & 5.6 & 42.9 & 36.4 & \\
\hline Caragana & 11.5 & & 25.7 & & & & 27.3 & 50.0 \\
\hline Vicia & 6.4 & & 14.3 & & & 57.1 & 4.5 & \\
\hline Thermopsis & 3.8 & 4.7 & 2.9 & 4.0 & 5.6 & 14.3 & & \\
\hline Lespedeza & 2.6 & & 5.7 & & & 14.3 & 4.5 & \\
\hline Gueldenstaedtia & 1.3 & 2.3 & & & 5.6 & & & \\
\hline Hedysarum & 1.3 & & 2.9 & & & 14.3 & & \\
\hline Lathyrus & 1.3 & & 2.9 & & & & 4.5 & \\
\hline Tibetia & 1.3 & 2.3 & & 4.0 & & & & \\
\hline Trifolium & 1.3 & & 2.9 & & & 14.3 & & \\
\hline
\end{tabular}

between the species richness and aboveground biomass of legumes and those of the community at two levels: across sites, and among plots within sites. To find environmental factors that are likely to regulate legume diversity and abundance, Pearson's correlation was applied to the relation between legume attributes and the attributes of community, climate, and soil, both across and within regions. Furthermore, information was compiled about legume aboveground biomass in natural grasslands across six continents to enable the status of legumes in Chinese grasslands to be compared with that of other natural grasslands in the world. Statistical analysis was performed using R (version 2.15.2; R Development Core Team 2012).

\section{RESULTS}

\section{Composition of Legumes}

Of the studied sites, $89.7 \%$ had at least one legume species recorded. Overall, 12 legume genera, (Astragalus, Oxytropis, Medicago, Caragana, Vicia, Thermopsis, Lespedeza, Gueldenstaedtia, Hedysarum, Lathyrus, Tibetia, and Trifolium) were recorded, all of which belong to the subfamily Papilionoideae (Table 2). The diversity of legume genera was higher in Inner Mongolia than on the Tibetan Plateau and was higher in the meadow and typical steppes than in the other grassland types. Astragalus, Oxytropis, and Medicago are the three dominant legume genera in Chinese grasslands and were present in $67.9 \%, 34.6 \%$, and $21.8 \%$ of the sites studied, respectively. Specifically, Oxytropis was present in $53.5 \%$ of the sites on the Tibetan Plateau and in $11.4 \%$ of the sites in Inner Mongolia.

More forage legume species were recorded in the grasslands of Inner Mongolia, whereas more toxic legumes were recorded on the Tibetan Plateau (Table 3). Among the recorded legumes, 
Table 3. Forage and toxic legumes observed in 78 sites from five grassland types in China.

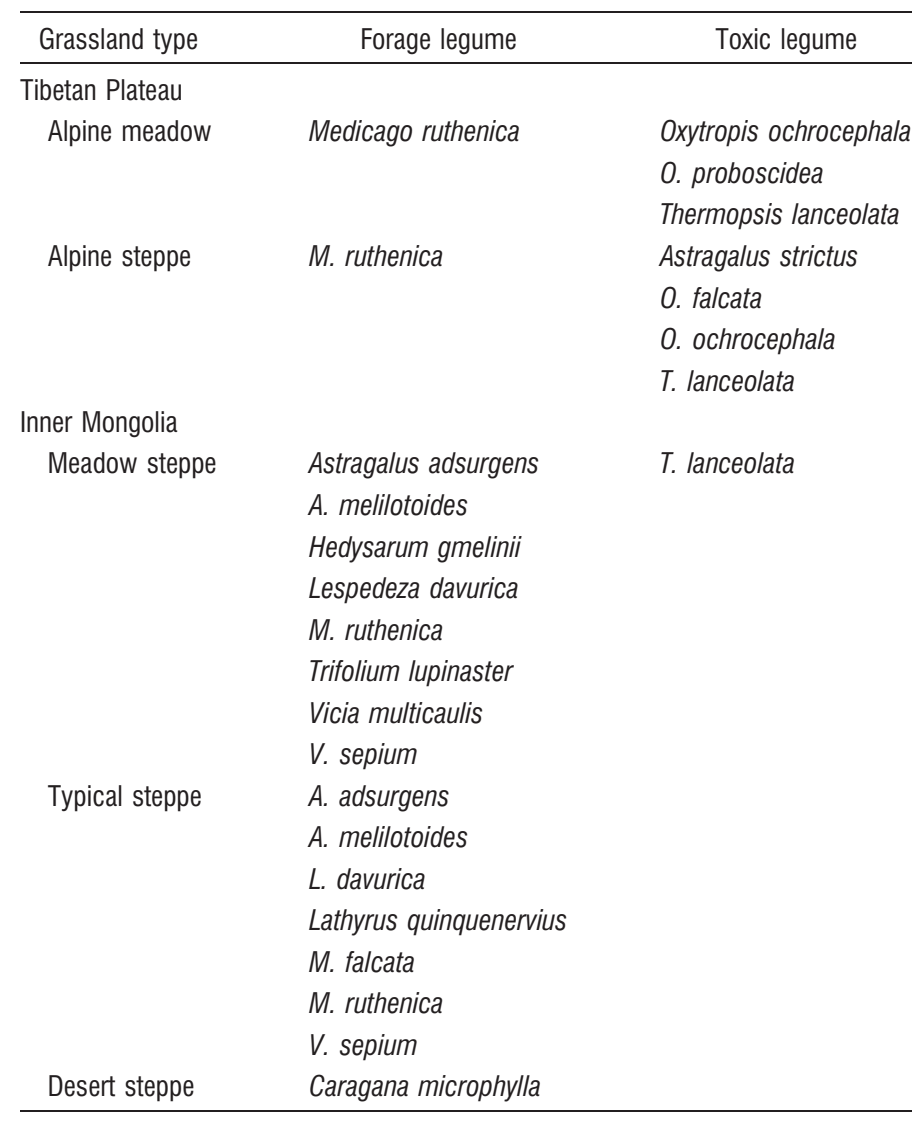

11 species (Astragalus adsurgens, A. melilotoides, Caragana microphylla, Hedysarum gmelinii, Lathyrus quinquenervius, Lespedeza davurica, Medicago falcata, M. ruthenica, Trifolium lupinaster, Vicia multicaulis, and V. sepium) are commonly considered as valuable forages and are listed in the China Forage Catalog. At least one of the above species was recorded in $51.4 \%$ of the sites studied in Inner Mongolia. On the Tibetan Plateau, M. ruthenica was the only forage legume, occurring in $14.0 \%$ of the sites studied. Five toxic legume species (A. strictus, Oxytropis ochrocephala, O. proboscidea, O. falcate, and Thermopsis lanceolata) were found in $23.3 \%$ of the sites studied on the Tibetan Plateau, whereas in Inner Mongolia, only one toxic legume (T. lanceolata) was found, in $2.9 \%$ of the sites studied.

\section{Legume Species Richness and Aboveground Biomass}

Median values are presented instead of averaged ones to avoid the influence of a few extreme values, because legume species richness and biomass varied substantially across sites (Table 4). Generally, within $1 \mathrm{~m}^{2}$ of grassland, only one legume species with an aboveground biomass of $1.1 \mathrm{~g}$ was present, accounting for $9.1 \%$ of species richness and $1.7 \%$ of the aboveground biomass of the community. Legume species richness and its percentage of the community total on the Tibetan Plateau (1 $\mathrm{m}^{-2}$ and $10.3 \%$ respectively) were close to those in Inner Mongolia $\left(1 \mathrm{~m}^{-2}\right.$ and $8.8 \%$ respectively). However, legume aboveground biomass and its percentage of the community total on the Tibetan Plateau $\left(1.43 \mathrm{~g} \cdot \mathrm{m}^{-2}\right.$ and $2.42 \%$, respectively) were 2.5 and 2.8 times those in Inner Mongolia $\left(0.57 \mathrm{~g} \cdot \mathrm{m}^{-2}\right.$ and $0.88 \%$, respectively). In particular, legume aboveground biomass and its percentage of the community total were much lower in typical steppe $\left(0.43 \mathrm{~g} \cdot \mathrm{m}^{-2}\right.$ and $0.62 \%$ respectively $)$ and desert steppe $\left(0.33 \mathrm{~g} \cdot \mathrm{m}^{-2}\right.$ and $0.60 \%$ respectively) than in the other three types of grassland, in which legume aboveground biomass varied from $1.31 \mathrm{~g} \cdot \mathrm{m}^{-2}$ to 3.24 $\mathrm{g} \cdot \mathrm{m}^{-2}$, and its percentage of the community total varied from $2.40 \%$ to $3.46 \%$.

\section{Associations Between Legume and Community Attributes}

Strong positive correlations between legume species richness and community species richness $(P<0.01$, Fig. 2a), and between the aboveground biomass of legumes and that of the community $(P<0.001$, Fig. 2 b), were found both in Inner Mongolia and on the Tibetan Plateau, as well as across all sites (Table 5). The percentage of legume species richness showed no correlation with community species richness in either region. However, the percentage of legume aboveground biomass in the community correlated positively to the community aboveground biomass across sites in Inner Mongolia $(P<0.05)$, but not on the Tibetan Plateau. Among the plots within sites, we also found significant correlations between legume species richness and community species richness for both regions

Table 4. Legume species richness, aboveground biomass, and their percentages of the corresponding parameters in communities. Median values are shown, with the ranges in parentheses.

\begin{tabular}{|c|c|c|c|c|c|c|}
\hline & $\operatorname{LSR}^{1}\left(m^{-2}\right)$ & $\mathrm{SR}\left(\mathrm{m}^{-2}\right)$ & PLSR (\%) & L-Biomass $\left(\mathrm{g} \cdot \mathrm{m}^{-2}\right)$ & Biomass $\left(\mathrm{g} \cdot \mathrm{m}^{-2}\right)$ & PL-Biomass (\%) \\
\hline Overall & $1.0(0-3.3)$ & $12.3(3.7-33)$ & $9.1(0-31.3)$ & $1.10(0-44.8)$ & $71.7(13.7-244.6)$ & $1.68(0-30.5)$ \\
\hline \multicolumn{7}{|l|}{ Region } \\
\hline Inner Mongolia & $1.0(0-3.3)$ & $13.0(3.7-33)$ & $8.8(0-19.4)$ & $0.57(0-44.8)$ & 70.6 (16.2-205.5) & $0.88(0-30.5)$ \\
\hline \multicolumn{7}{|l|}{ Grassland type } \\
\hline Alpine meadow & $1.0(0-3.0)$ & $13.0(7.7-26.3)$ & $9.4(0-18.2)$ & $1.60(0-22.3)$ & $96.5(40.1-244.6)$ & $3.46(0-15.9)$ \\
\hline Typical steppe & $1.0(0-2.7)$ & $12.7(3.7-33.0)$ & $8.9(0-19.4)$ & $0.43(0-44.8)$ & $65.2(36.2-205.5)$ & $0.62(0-30.5)$ \\
\hline Desert steppe & $0.7(0-1.3)$ & $11.7(7.3-15.3)$ & $5.2(0-9.1)$ & $0.33(0-6.6)$ & 49.1 (16.2-93.5) & $0.60(0-7.0)$ \\
\hline
\end{tabular}

${ }^{1}$ LSR indicates legume species richness; SR, species richness of a community; PLSR, percentage of legume species richness in a community; L-Biomass, aboveground biomass of legumes; Biomass, aboveground biomass of a community; and PL-Biomass, percentage of aboveground biomass of legumes in a community. 

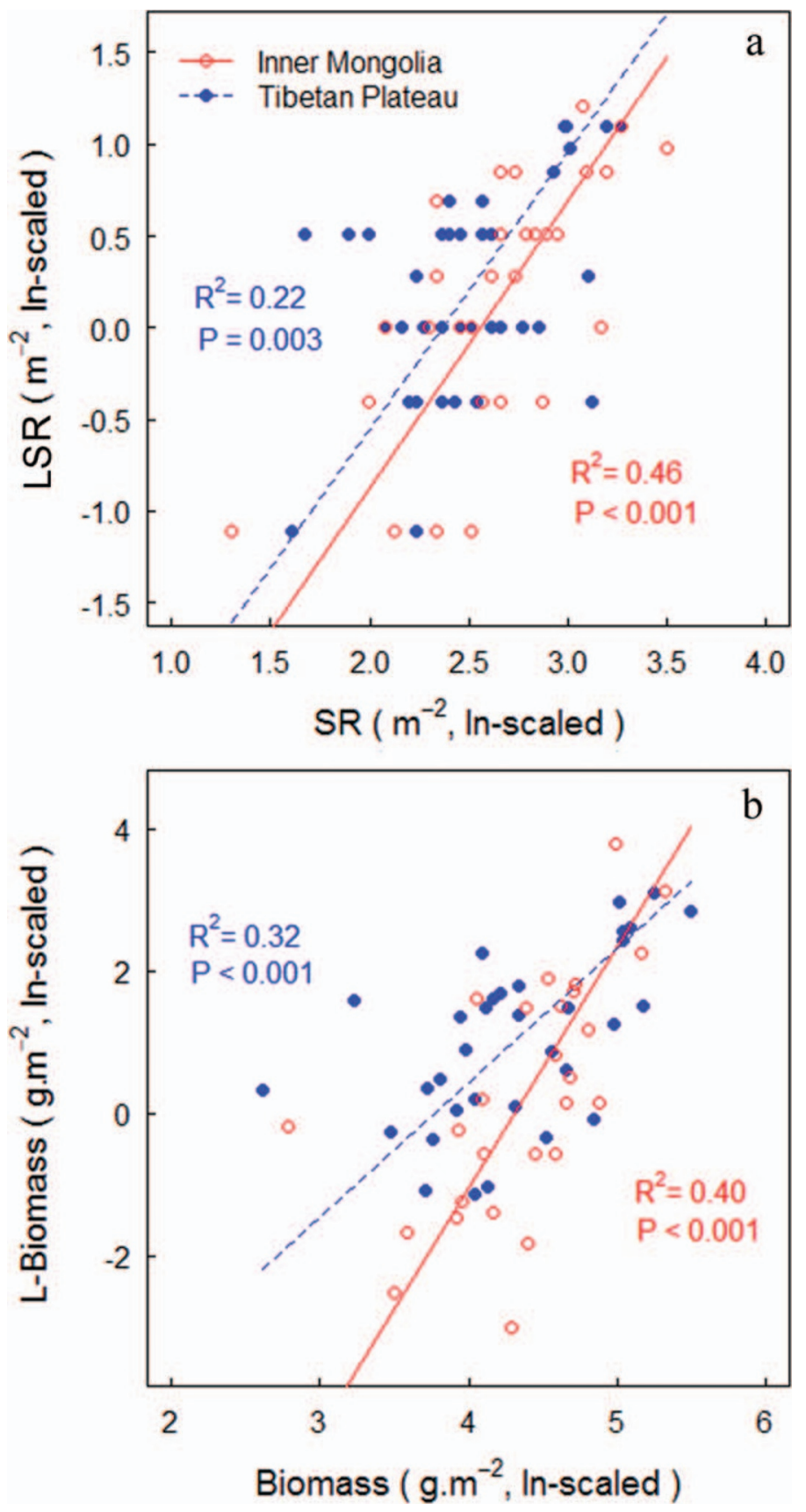

Figure 2. a, Legume species richness (LSR) in relation to community species richness (SR). b, Legume aboveground biomass (L-Biomass) in relation to aboveground biomass of the community (Biomass) for each region. Standardized major axes with $R^{2}$ and $P$ for each region are shown. Data were In-transformed before analysis, and sites with no legumes were not included.

$(P<0.01$, Fig. 3a), and between the aboveground biomass of legumes and that of the community on the Tibetan Plateau $(P<0.01$, Fig. 3b).

\section{Associations Between Legume, Climate, and Soil Attributes}

Legume species richness and aboveground biomass correlated positively with growing-season precipitation across all sites $(P<0.05$ and $P<0.01$ respectively, Table 5$)$ and in Inner Mongolia $(P<0.001$ and $P<0.1$ respectively, Figs. $4 \mathrm{~b}$ and $4 \mathrm{~d})$.
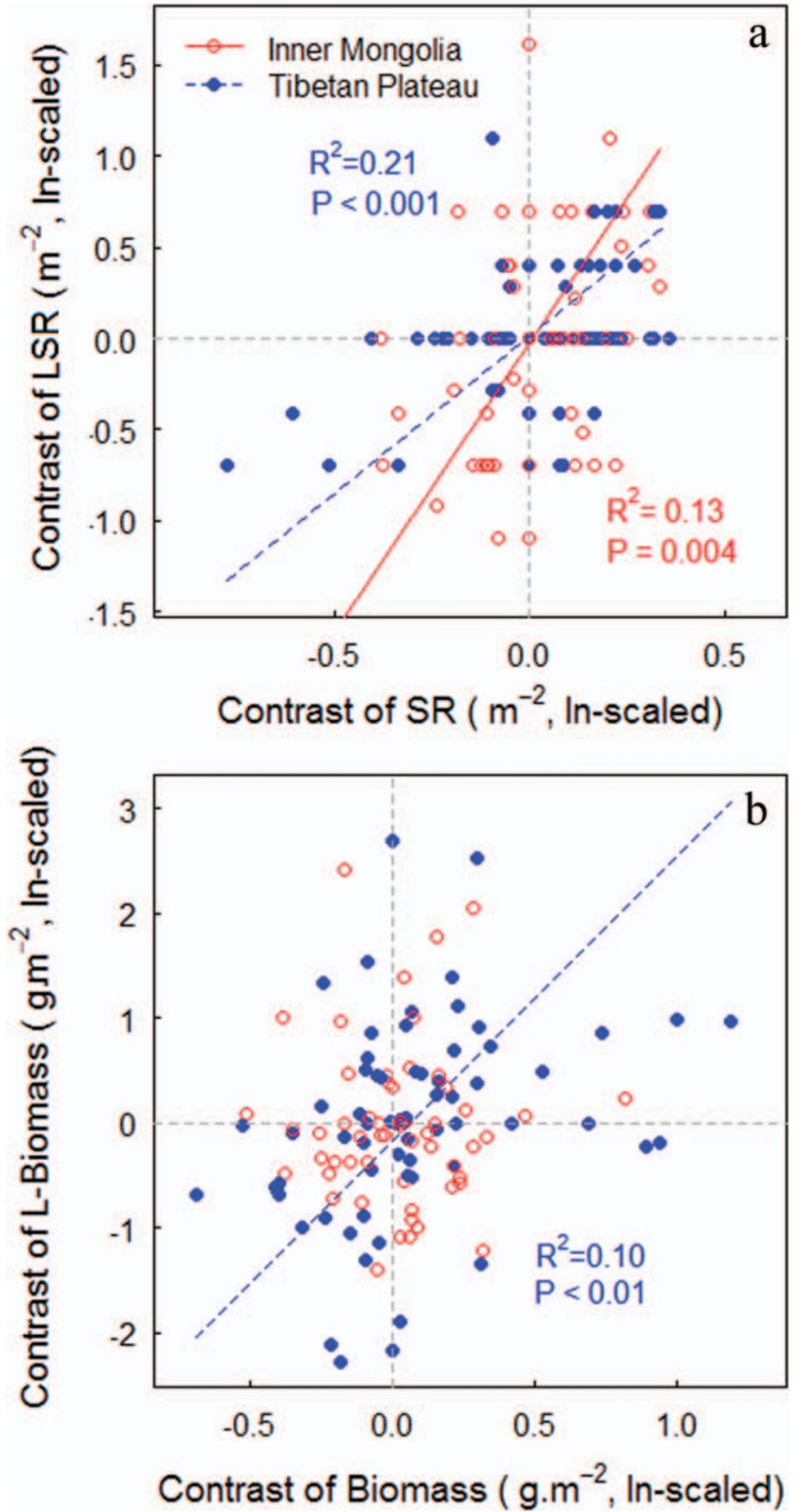

Figure 3. Comparison of relations between legumes and total plant community for plots within each site. a, Legume species richness (Contrast of LSR) in relation to community species richness (Contrast of SR). $\mathbf{b}$, Legume aboveground biomass (Contrast of L-Biomass) relative to community aboveground biomass (Contrast of Biomass). Standard major axes with $R^{2}$ and $P$ for each region are shown when significant at $P<0.05$. Raw data were transformed by In $(1+x)$ before contrasts were calculated among plots within sites, and sites with no legumes were not included.

However, the associations between legume species richness and aboveground biomass with growing-season temperature differed between the two regions. In Inner Mongolia, legume species richness and aboveground biomass correlated negatively with growing-season temperature $(P<0.01$ and $P<0.1$ respectively, Figs. $4 \mathrm{a}$ and $4 \mathrm{c}$ ), while on the Tibetan Plateau, a positive correlation was observed $(P<0.1$ for the biomass, Fig. 
Table 5. Pearson's correlation coefficient values for relations between legume attributes and biotic and abiotic variables.

\begin{tabular}{|c|c|c|c|c|c|c|c|}
\hline Variable & $\mathrm{SR}\left(\mathrm{m}^{-2}\right)$ & Biomass $\left(\mathrm{g} \cdot \mathrm{m}^{-2}\right)$ & GST $\left({ }^{\circ} \mathrm{C}\right)$ & $\mathrm{GSP}\left(\mathrm{mm} \cdot \mathrm{yr}^{-1}\right)$ & STN (\%) & $\operatorname{SAP}\left(\mu g \cdot g^{-1}\right)$ & SOC (\%) \\
\hline \multicolumn{8}{|l|}{ Overall } \\
\hline $\mathrm{LSR}^{1}$ & $0.55^{\star \star \star \star 2}$ & $0.26^{\star \star}$ & -0.06 & $0.30 * *$ & 0.07 & 0.15 & 0.07 \\
\hline PLSR & -0.13 & -0.10 & -0.17 & -0.01 & -0.06 & 0.00 & -0.11 \\
\hline L-Biomass & $0.36^{\star \star \star}$ & $0.54^{\star \star \star \star}$ & $-0.25^{\star}$ & $0.35^{\star \star \star}$ & $0.35^{\star \star \star}$ & $0.33^{\star *}$ & $0.27^{\star \star}$ \\
\hline PL-Biomass & 0.17 & 0.20 & $-0.31^{\star \star}$ & 0.20 & $0.29 * \star$ & $0.27^{\star \star}$ & 0.20 \\
\hline \multicolumn{8}{|l|}{ Tibetan } \\
\hline \multicolumn{8}{|l|}{ Plateau } \\
\hline LSR & $0.47^{\star \star \star}$ & 0.05 & 0.25 & 0.11 & -0.06 & 0.14 & -0.08 \\
\hline PLSR & -0.21 & $-0.34^{\star \star}$ & 0.17 & $-0.35^{\star \star}$ & $-0.34^{\star \star}$ & -0.21 & $-0.36^{\star \star}$ \\
\hline L-Biomass & 0.40 ** & $0.57^{\star \star \star \star}$ & $0.30 *$ & 0.21 & $0.29 *$ & $0.34^{\star}$ & 0.17 \\
\hline PL-Biomass & 0.12 & 0.05 & 0.15 & -0.06 & 0.08 & 0.15 & -0.13 \\
\hline \multicolumn{8}{|l|}{ Inner } \\
\hline \multicolumn{8}{|l|}{ Mongolia } \\
\hline LSR & $0.68^{\star * \star *}$ & $0.57^{\star \star \star \star}$ & $-0.54^{\star \star \star}$ & $0.57^{\star \star \star \star}$ & $0.49 * *$ & $0.35^{\star}$ & $0.50^{\star \star \star}$ \\
\hline PLSR & 0.05 & $0.31^{\star}$ & -0.26 & 0.29 & 0.23 & 0.16 & 0.20 \\
\hline L-Biomass & $0.55^{\star \star \star}$ & $0.63^{\star * * *}$ & $-0.33^{\star}$ & $0.36^{\star}$ & 0.25 & 0.08 & 0.26 \\
\hline PL-Biomass & $0.43^{\star *}$ & 0.40 ** & -0.15 & 0.20 & 0.19 & -0.03 & 0.20 \\
\hline
\end{tabular}

${ }^{1}$ LSR indicates legume species richness; PLSR, percentage of legume species richness in a community; L-Biomass, aboveground biomass of legumes; PL-Biomass, percentage of aboveground biomass of legumes in a community; SR, species richness of a community; and Biomass, aboveground biomass of a community. Data for LSR, PLSR, L-Biomass, and PL-Biomass, SR, and Biomass were In-transformed prior to analysis, and sites with no legumes recorded were not included.

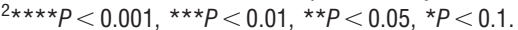

4c).For the soil attributes, no correlations between legume species richness with soil total $\mathrm{N}$, available phosphorus, or organic carbon concentration were observed across all sites or on the Tibetan Plateau, but positive correlations were found in Inner Mongolia $(P<0.05, P<0.1$, and $P<0.01$, respectively, Table 5). In addition, the aboveground biomass of legumes and its percentage of the community total correlated positively to soil total $\mathrm{N}(P<0.01$ and $P<0.05$, respectively), available phosphorus $(P<0.05$ both $)$, and organic carbon concentration $(P<0.05$ for the biomass $)$ across all sites studied.

\section{DISCUSSION}

\section{Possible Influence of Environmental Factors on Legumes}

Strong positive correlations between the species richness and aboveground biomass of legumes with those of the community were observed across sites on the Tibetan Plateau and in Inner Mongolia. Moreover, for both regions, the correlations between legume species richness and aboveground biomass with growing-season temperature and precipitation were similar to those between the corresponding community variables and the climate (Ma et al. 2010). These consistencies between legumes and nonlegumes may arise from their common demand on energy and moisture, despite the fact that the two groups differ in their ability to use atmospheric $\mathrm{N}$.

The spatial pattern of legume diversity and biomass may be driven mainly by climate. On the Tibetan Plateau, the low growing-season temperature may have reduced the legume biomass, whereas in Inner Mongolia, low precipitation combined with a high temperature during the growing season may be the main limitation for legume growth. The mean temperature in the growing season increases, but precipitation decreases, from northeast to southwest in Inner Mongolia, and legume species richness and aboveground biomass decrease from meadow steppe to typical steppe to desert steppe, correspondingly.

Although legume species richness in Inner Mongolia and legume biomass on the Tibetan Plateau showed positive correlations with soil nutrient availability, the effects of soil factors can be explained largely by the climate. Besides, among plots within sites, the positive correlations between the species richness of legumes and that of the community in both regions may arise from the difference in microenvironment, while the positive correlation between the legume biomass and that of the community on the Tibetan Plateau may indicate positive effects of the legumes on community biomass production (Spehn et al. 2002; Marquard et al. 2009; Schmidtke et al. 2010).

\section{Economic Value of Legumes in Chinese Natural Grasslands}

Diverse legume genera with abundant forage species were found in the grassland of Inner Mongolia, especially in meadow and typical steppes. However, the aboveground biomass of legumes in the grasslands in Inner Mongolia was only 0.57 $\mathrm{g} \cdot \mathrm{m}^{-2}$, which was $40 \%$ of that on the Tibetan Plateau, and was much lower than that of most other natural grasslands around the world (Table 6). As mentioned above, low precipitation with high temperature in the growing season is probably the main reason limiting legume biomass in Inner Mongolia, especially in desert and typical steppes. Moreover, because species diversity is more robust against disturbance than population size and biomass (He and Hubbell 2011), the high total legume diversity, but low biomass, in Inner Mongolia may be attributed partly to the loss of legume habitat due to largescale grassland degradation (Li 1997; Jiang et al. 2006). In particular, animal grazing in Inner Mongolia has been reported 


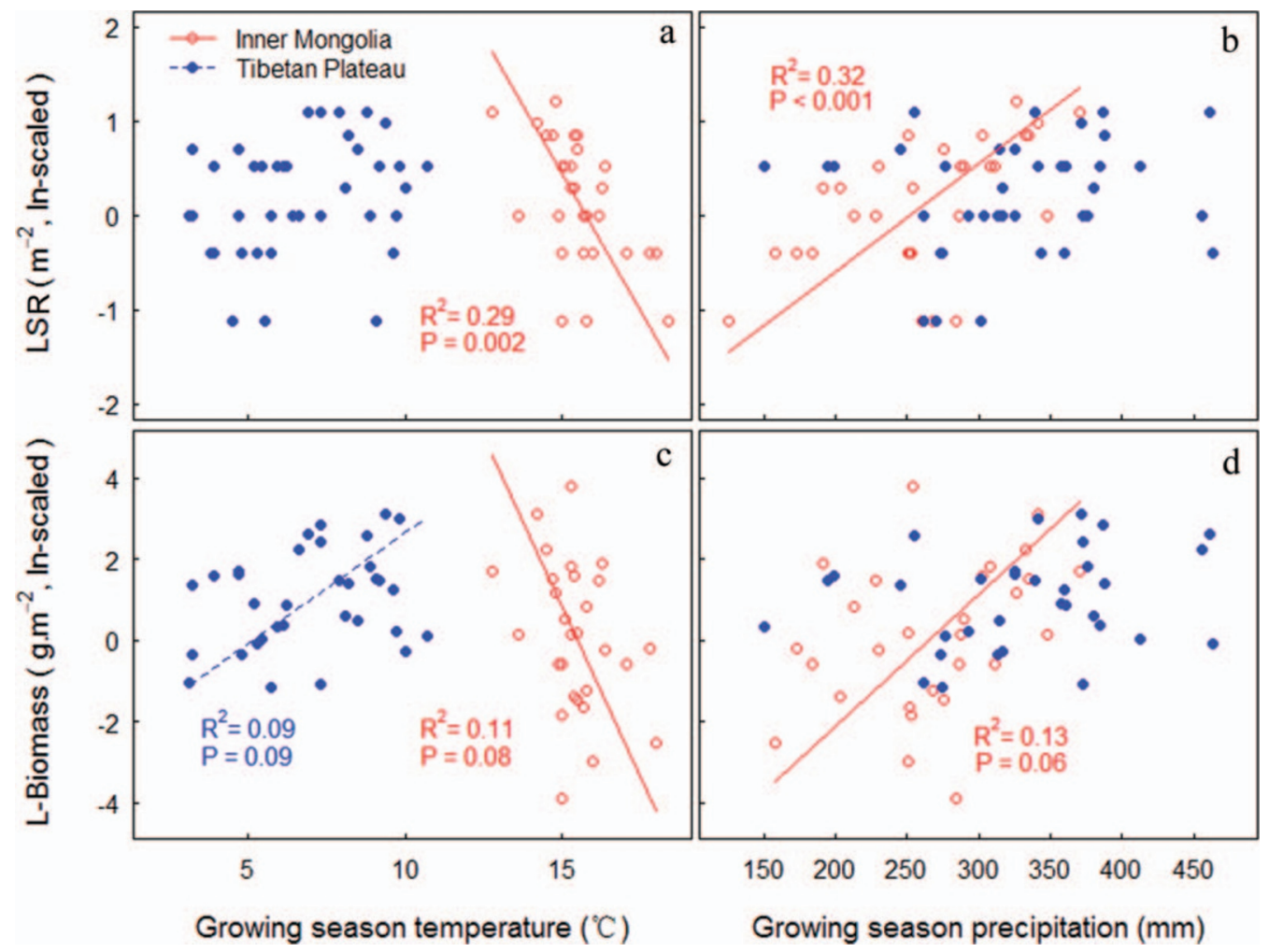

Figure 4. Relation of legume species richness (LSR) to a, growing-season temperature and $\mathbf{b}$, growing-season precipitation for each region, and relation of legume aboveground biomass (L-Biomass) to c, growing-season temperature and $\mathbf{d}$, growing-season precipitation for each region. Standard major axes with $R^{2}$ and $P$ for each region are shown when significant at $P<0.10$. Data of legume attributes were In-transformed before analysis, and sites with no legumes were not included.

to reduce community aboveground biomass of meadow and typical steppes by $55 \%$ and $60 \%$, respectively, in comparison to relevant grasslands that were fenced for 6-24 years (Bai et al. 2008). Based on the positive correlations between legume biomass and its percentage of the community total with community biomass in Inner Mongolia and the preference for legumes by the animals, we may infer that legume biomass is reduced by animal grazing in Inner Mongolia.
Legume genera diversity is relatively lower on the Tibetan Plateau than in Inner Mongolia. This pattern may be driven by the extreme alpine environment on the Tibetan Plateau. Only a few legume genera, such as Astragalus and Oxytropis, have passed the environmental filter successfully and became dominant on the vast plateau. For example, Medicago on the Tibetan Plateau was present only in a few sites, which have a higher growing-season temperature $\left(7.5^{\circ} \mathrm{C}\right)$ and growing-

Table 6. Legume aboveground biomass (L-Biomass) and percentage in the community (PL-Biomass) of the major grassland ecosystems around the world.

\begin{tabular}{|c|c|c|c|c|c|}
\hline Grassland type & Country & Location & L-Biomass $\left(\mathrm{g} \cdot \mathrm{m}^{-2}\right)$ & PL-Biomass (\%) & Reference \\
\hline Alpine grassland & China & $\begin{array}{l}\text { lat } 30^{\circ} 19^{\prime}-37^{\circ} 17^{\prime} \mathrm{N}, \\
\quad \text { long } 90^{\circ} 48^{\prime}-101^{\circ} 29^{\prime} \mathrm{E}\end{array}$ & $1.4(0-22.3)$ & $2.4(0-19.3)$ & Current study \\
\hline Temperate grassland & China & $\begin{array}{l}\text { lat } 41^{\circ} 47^{\prime}-50^{\circ} 11^{\prime} \mathrm{N}, \\
\quad \text { long } 111^{\circ} 50^{\prime}-120^{\circ} 7^{\prime} \mathrm{E}\end{array}$ & $0.6(0-44.8)$ & $0.9(0-30.5)$ & Current study \\
\hline Tallgrass prairie & America & lat $37^{\circ} 17^{\prime} \mathrm{N}$, long $96^{\circ} 40^{\prime} \mathrm{W}$ & $10.5 \pm 0.9$ & $2.4-3.0$ & $\begin{array}{l}\text { Briggs and Knapp 1995; } \\
\text { Towne and Knapp } 1996\end{array}$ \\
\hline Oak savanna & America & lat $45^{\circ} 24^{\prime} \mathrm{N}$, long $93^{\circ} 12^{\prime} \mathrm{W}$ & 11.0 & $6.0^{1}$ & Ritchie et al. 1998 \\
\hline Floodplain grassland & The Netherlands & lat $52^{\circ} 32^{\prime} \mathrm{N}$, long $6^{\circ} 36^{\prime} \mathrm{E}$ & $7.0 \pm 4.0$ & 2.8 & Bakker et al. 2004 \\
\hline Calcareous grassland & Switzerland & lat $47^{\circ} 33^{\prime} \mathrm{N}$, long $7^{\circ} 34^{\prime} \mathrm{E}$ & $4.0-12.0$ & $4.1-5.2$ & Leadley et al. 1999 \\
\hline Savanna & South Africa & lat $24^{\circ} 36^{\prime} \mathrm{S}$, long $28^{\circ} 41^{\prime} \mathrm{E}$ & 8.2 & 3.5 & Korn and Korn 1989 \\
\hline Perennial grassland & New Zealand & lat $37^{\circ} 45^{\prime} \mathrm{S}$, long $175^{\circ} 15^{\prime} \mathrm{E}$ & $5.0-47.0$ & $3.0-30.0$ & Wardle et al. 1999 \\
\hline Humid grassland & New Zealand & lat $40^{\circ} 19^{\prime} \mathrm{S}$, long $175^{\circ} 51^{\prime} \mathrm{E}$ & $26.0-90.0$ & $5.0-14.0$ & Smith 1992 \\
\hline Flooding pampa & Argentina & lat $36^{\circ} 30^{\prime} \mathrm{S}$, long $58^{\circ} 30^{\prime} \mathrm{W}$ & $95.0-111.0$ & $9.6-22.7$ & Striker et al. 2011 \\
\hline
\end{tabular}

${ }^{1} 14.7 \%$ for ungrazed grassland. 
season precipitation $(309 \mathrm{~mm})$ on average than sites with Astragalus $\left(5.9^{\circ} \mathrm{C}\right.$ and $274 \mathrm{~mm}$, respectively) or Oxytropis $(4.8$ ${ }^{\circ} \mathrm{C}$ and $282 \mathrm{~mm}$, respectively). Oxytropis, the second-most dominant legume genus on the Tibetan Plateau, is notorious as the most important "locoweed" in grassland areas because it contains a large number of species toxic to grazing animals. Environmental filtering may explain why there are more toxic legume species on the Tibetan Plateau than in Inner Mongolia.

\section{Ecological Value of Legumes in Chinese Grasslands}

The amount of $\mathrm{N}$-fixation by legumes can be determined largely by the legume species and their biomass. On the one hand, all of the legume genera recorded in this study belong to the subfamily Papilionoideae, of which $98 \%$ of the examined species are able to form nodules (Allen and Allen 1981; de Faria et al. 1989). Moreover, all the genera with $41 \%$ of the species recorded have been shown to nodulate (Chen and Wang 2011). Therefore, we may infer that most of the legume species in Chinese grasslands can fix atmospheric N. On the other hand, both the aboveground biomass of legumes $\left(1.1 \mathrm{~g} \cdot \mathrm{m}^{-2}\right)$ and its percentage of the community total $(1.7 \%)$ in Chinese grasslands are low in comparison with most other natural grasslands around the world. According to Yang et al. (2011), legumes derive $50 \%$ to $92 \%$ of their tissue $\mathrm{N}$ from the atmosphere, and fix $10-11.5 \mathrm{~kg} \cdot \mathrm{N} \cdot \mathrm{ha}^{-1}$ annually in ungrazed natural grasslands of alpine meadow on the Tibetan Plateau and temperate steppe in Inner Mongolia. Given the same Nfixing ability per unit of aboveground biomass of legumes, legumes in Chinese grasslands will fix about $0.14 \mathrm{~kg} \cdot \mathrm{N} \cdot \mathrm{ha}^{-1}$ to $0.90 \mathrm{~kg} \cdot \mathrm{N} \cdot \mathrm{ha}^{-1}$ annually, which is less than $10 \%$ of the value for reported ungrazed grasslands in China or $1 \%$ of the global average in pasture and fodder legumes (Smil 1999; Herridge et al. 2008). As a result, the ecological value of legumes (e.g., improving soil fertility and enhancing community productivity) in Chinese grasslands are limited severely by the low legume biomass.

\section{IMPLICATIONS}

Legumes in Chinese natural grasslands have substantial economic and ecological potential, but their current value is constrained severely by the low biomass. To increase legume biomass in these grasslands, possible measures are (1) sowing seeds of forage legumes in the grasslands according to local climate; (2) irrigating the grasslands of Inner Mongolia, especially the typical steppe, during the growing season; and (3) mitigating grassland degradation though management (e.g., reducing grazing intensity). We believe that it is important to explore the potential value of legumes in these grasslands and to manage the grasslands in a more sustainable way, which in turn will enhance the productivity and ecosystem stability of the grasslands.

\section{ACKNOWLEDGEMENTS}

We thank the members of the Peking University sampling team for their assistance in data collection, and Professor Jacob Weiner from the University of Copenhagen for his help with the manuscript.

\section{LITERATURE CITED}

Allen, 0. N., and E. K. Allen. 1981. The Leguminosae, a sourcebook of characteristics, uses and nodulation. Madison, WI, USA: University of Wisconsin Press. xxix $p$.

Bal, Y., J. Wu, Q. XIng, Q. Pan, J. Huang, D. Yang, and X. Han. 2008. Primary production and rain use efficiency across a precipitation gradient on the Mongolia Plateau. Ecology 89:2140-2153.

Bakker, E. S., H. Olff, M. Boekhoff, J. M. Gleichman, and F. Berendse. 2004. Impact of herbivores on nitrogen cycling: contrasting effects of small and large species. Oecologia 138:91-101.

BriGgS, J. M., AND A. K. KnapP. 1995. Interannual variability in primary production in tallgrass prairie: climate, soil moisture, topographic position, and fire as determinants of aboveground biomass. American Journal of Botany 82:10241030.

Chen, W. X., and E. T. Wang. 2011. Zhong guo gen liu jun. [Rhizobia in China.] Beijing, China: Science Press. $464 \mathrm{p}$.

Chinese Academy of Sciences, Editorial Committee of Vegetation Map of China. 2007. Zhong hua ren min gong he guo zhi bei tu $(1: 1000000)$. [Vegetation map of the People's Republic of China (1:1000 000).] Beijing, China: Geological Publishing House. p. 49-264.

de Faria, S. M., G. P. Lewis, J. I. Sprent, and J. M. Sutherland. 1989. Occurrence of nodulation in the Leguminosae. New Phytologist 111:607-619.

Dewhurst, R. J., L. Delaby, A. Moloney, T. Boland, and E. Lewis. 2009. Nutritive value of forage legumes used for grazing and silage. Irish Journal of Agricultural and Food Research 48:167-187.

Food and Agriculture Organization of the United Nations. 2013. AgP - grasslands, rangelands and forage crops. Available at: http://www.fao.org. Accessed 17 August 2013.

He, F., AND S. P. HubBell. 2011. Species-area relationships always overestimate extinction rates from habitat loss. Nature 473:368-371.

Herridge, D. F., M. B. Peoples, and R. M. Boddey. 2008. Global inputs of biological nitrogen fixation in agricultural systems. Plant and Soil 311:1-18.

Hiumans, R. J., S. E. Cameron, J. L. Parra, P. G. Jones, and A. Jarvis. 2005. Very high resolution interpolated climate surfaces for global land areas. International Journal of Climatology 25:1965-1978.

Grassland Research Institute of Chinese Academy of Agricultural Sciences. 2009. Zhong guo mu cao zhong zhi zi yuan xin xi wang. [China Forage Resource Information.] Available at: http://www.chinaforage.com. Accessed 2 May 2012.

JiAnG, G., X. HAN, AND J. WU. 2006. Restoration and management of the Inner Mongolia grassland require a sustainable strategy. AMBIO: A Journal of the Human Environment 35:269-270.

Kang, L., X. G. Han, Z. B. Zhang, And O. J. Sun. 2007. Grassland ecosystems in China: review of current knowledge and research advancement. Philosophical Transactions of the Royal Society B: Biological Sciences 362:997-1008.

Korn, H., And U. KoRn. 1989. The effect of gerbils (Tatera brantsii) on primary production and plant species composition in a southern African savanna. Oecologia 79:271-278.

Leadley, P. W., P. A. Niklaus, R. Stocker, and C. Körner. 1999. A field study of the effects of elevated $\mathrm{CO}_{2}$ on plant biomass and community structure in a calcareous grassland. Oecologia 118:39-49.

LI, B. 1997. Zhong guo bei fang cao di tui hua ji qi fang zhi dui ce. [The rangeland degradation in north China and its preventive strategy.] Scientia Agricultura Sinica 30:1-9.

Ma, W. H., Z. L. Liu, Z. H. Wang, W. Wang, C. Z. Liang, Y. H. Tang, J. S. He, and J. Y. FANG. 2010. Climate change alters interannual variation of grassland aboveground productivity: evidence from a 22-year measurement series in the Inner Mongolian grassland. Journal of Plant Research 123:509-517.

Marquard, E., A. Weigelt, V. M. Temperton, C. Roscher, J. Schumacher, N. Buchmann, M. FISCHER, W. W. WeISSER, AND B. SChMid. 2009. Plant species richness and functional composition drive overyielding in a six-year grassland experiment. Ecology 90:3290-3302.

Olsen, S., C. Cole, F. Watanabe, and L. Dean. 1954. Estimation of available phosphorus in soils by extraction with sodium bicarbonate. Washington, DC, USA: US Dept of Agriculture. p. 1-19. 
R Development Core Team. 2012. R: a language and environment for statistical computing. Vienna, Austria: R Foundation for Statistical Computing. Available at: http://www.r-project.org. Accessed 2 November 2012.

Ritchie, M. E., D. Tilman, and J. M. H. Knops. 1998. Herbivore effects on plant and nitrogen dynamics in oak savanna. Ecology 79:165-177.

Rochon, J. J., C. J. Doyle, J. M. Greef, A. Hopkins, G. Molle, M. Sitzia, D. Scholefield, AND C. J. Smith. 2004. Grazing legumes in Europe: a review of their status, management, benefits, research needs, and future prospects. Grass and Forage Science 59:197-214.

Roscher, C., S. Thein, A. Weigelt, V. M. Temperton, N. Buchmann, and E. D. Schulze. 2011. $\mathrm{N}_{2}$ fixation and performance of 12 legume species in a 6-year grassland biodiversity experiment. Plant and Soil 341:333-348.

SchmidTKe, A., T. RotTstock, U. Gaedke, and M. Fischer. 2010. Plant community diversity and composition affect individual plant performance. Oecologia 164:665-677.

SchriRe B. D., G. P. Lewis, And M. Lavin. 2005. Biogeography of the Leguminosae. In: G. Lewis, B. Schrire, B. Mackinder, and M. Lock [EDS.]. Legumes of the world. London, UK: Royal Botanic Gardens, Kew. p. 21-54.

SMLL, V. 1999. Nitrogen in crop production: An account of global flows. Global Biogeochemical Cycles 13: 647-662.

SмITH, V. 1992. Effects of nitrogen:phosphorus supply ratios on nitrogen fixation in agricultural and pastoral ecosystems. Biogeochemistry 18:19-35.

Spehn, E. M., M. Scherer-Lorenzen, B. Schmid, A. Hector, M. C. Caldeira, P. G. Dimitrakopoulos, J. A. Finn, A. Jumpponen, G. O’Donnovan, J. S. Pereira, E. D. Schulze, A. Y. Troumbis, AND C. Korner. 2002. The role of legumes as a component of biodiversity in a cross-European study of grassland biomass nitrogen. Oikos 98:205-218.

Sprent, J. I., and H. S. Gehlot. 2010. Nodulated legumes in arid and semi-arid environments: are they important? Plant Ecology \& Diversity 3:211-219.
Striker, G. G., F. P. O. Mollard, A. A. Grimoldi, R. J. C. Leon, and P. Insausti. 2011. Trampling enhances the dominance of graminoids over forbs in flooded grassland mesocosms. Applied Vegetation Science 14:95-106.

Towne, E. G., And A. K. Knapp. 1996. Biomass and density responses in tallgrass prairie legumes to annual fire and topographic position. American Journal of Botany 83:175-179.

Wang, J. J., B. Y. ZhaO, Z. F. Fan, And Y. Z. Silang. 2007. Xi zang cao yuan feng cao fen bu wei hai ji qi fang zhi. [Locoweeds in the Tibetan grasslands: their distribution, harm, and prevention.] Grassland and Animal Husbandry 6:36-40.

Wardle, D. A., K. I. Bonner, G. M. Barker, G. W. Yeates, K. S. Nicholson, R. D. Bardgett, R. N. Watson, and A. Ghanl. 1999. Plant removals in perennial grassland: vegetation dynamics, decomposers, soil biodiversity, and ecosystem properties. Ecological Monographs 69:535-568.

Warton, D., AND J. Ormerod. 2007. Smatr: (Standardised) Major Axis estimation and testing routines. Available at: http://bio.mq.edu.au/research/groups/ecology// SMATR/. Accessed 8 April 2012.

XI, L., AND L. MA. 2003. Cao di du cao ji dou de yan jiu xian zhuang ji jin zhan. [Current research progress on grassland poisonous weeds. Oxytropis.] Grassland and Turf 3:19-22.

Xu, Z. 2004. Zhong guo mu cao shou ce. [Forage manual of China.] Beijing, China: Chemical Industry Press. $46 \mathrm{p}$.

Yang, B., N. QlaO, X. Xu, and H. Ouyang. 2011. Symbiotic nitrogen fixation by legumes in two Chinese grasslands estimated with the ${ }^{15} \mathrm{~N}$ dilution technique. Nutrient Cycling in Agroecosystems 91:91-98.

ZHu, X. Y., Y. F. Du, J. Wen, and B. J. BAO. 2007. Legumes of China: a checklist. Reading, UK:International Legume Database \& Information Service (ILDIS), School of Biological Sciences, University of Reading. viii $p$. 